\title{
The Immunity Network with Diverse Recognitions in TCR
}

\author{
Takayuki Yamaguchi Member (Oita National College of Technology,yamaguti@oita-ct.ac.jp) \\ Masahiro Fukata Non-member (Oita National College of Technology) \\ Yasutaka Aramaki Non-member (Oita National College of Technology) \\ Zheng Tang Non-member (Toyama University) \\ Hiroki Tamura Member (Miyazaki University) \\ Masahiro Ishii Non-member (Toyama University)
}

Keywords : immune response, immunity network, T cell receptor, pattern recognition system

\section{Introduction}

Recently, information processing ability of immune has been researched to be able to be useful for a computer system. But most of the researchers consider only a basic part of the interaction between $\mathrm{B}$ cells and $\mathrm{T}$ cells. Therefore, we propose a new immunity network model has the same function that a $\mathrm{T}$ cell receptor has. We applied to the pattern recognition system and showed usability.

\section{Immune Network}

There are antigen(Ag), antibody(Ab), B cells(B), TCR, $\mathrm{T}_{\mathrm{H}}$ cells $\left(T_{H}\right)$ and $T_{S}$ cells $\left(T_{S}\right)$ as cells about immune response. At first, an antigen that invaded the body is taken in by B cells and the antigen presentation is performed.The $T_{H}$ cells recognize the antigen presentation through TCR and secrete interleukin( $\mathrm{IL}+$ ) activating immune response. In the case of this antigen recognition, one TCR reacts to plural similar transformed antigens.B cells receive interleukin(IL+) and generate an antibody. When the antigen is removed by the antibody, secretion of interleukin(IL-) controlling antibody production by $\mathrm{T}_{\mathrm{S}}$ cells cased by increase of the antibody with excessive antibody production and immune response is finished.

The above is a process of immune response and shows an immunity network in Fig.1.

\section{Simulation}

We considered that an immunologic phenomenon that one TCR can recognize plural similar antigens can correspond to recognition of the plural transformation patterns that had similarity in engineering. In this paper, we considered the pattern that rotated, shifted, magnified and reduced as a kind of this transformation pattern. We simulated pattern recognition and showed the result in Fig.2, Fig.3.

\section{Conclusion}

We planned improvement of the partial function in this study by taking in a work of TCR. However, a work of more cells affects real immune. Functions can improve more by taking in the work.

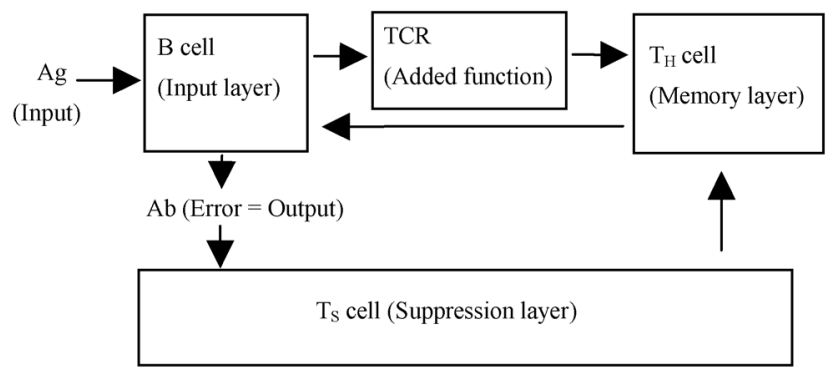

Fig. 1. The immunity network model

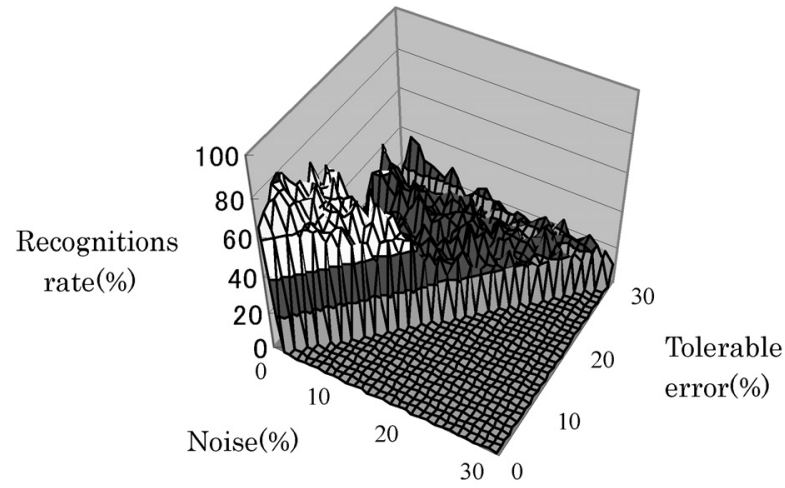

Fig. 2. Simulation result of recognition rate by immunity network with TCR function

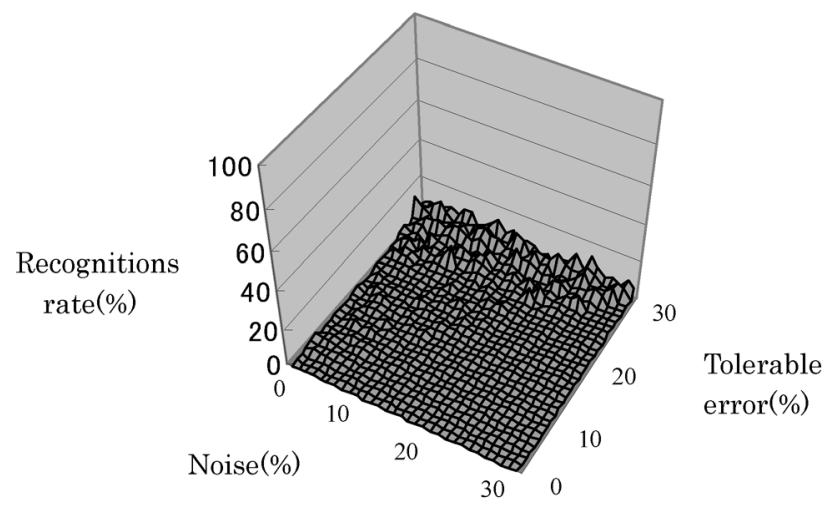

Fig. 3. Simulation result of recognition rate by immune network without TCR function 


\section{TCR の認識多様性を考慮した免疫的ネットワーク}

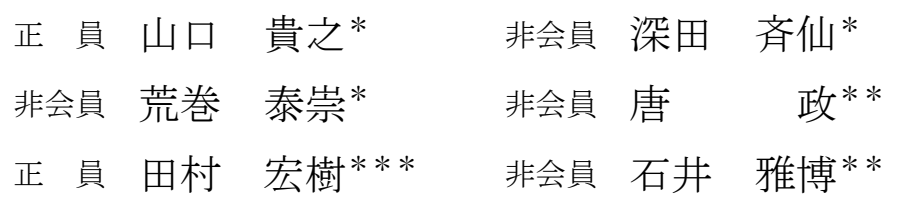

The Immunity Network with Diverse Recognitions in TCR

Takayuki Yamaguchi*, Member, Masahiro Fukata*, Non-member, Yasutaka Aramaki*, Non-member, Zheng Tang**, Non-member, Hiroki Tamura***, Member, Masahiro Ishii**, Non-member

Recently, biological superior information processing ability has been researched to be able to be useful for a computer system. Especially, neural networks about brain and nervous system have been researched. Immunity network models based on biological immune response network also have been researched, but most of the researchers consider only a basic part of the interaction between $\mathrm{B}$ cells and $\mathrm{T}$ cells. The recent research has been reported a thing that the function of $\mathrm{T}$ cell receptor (TCR) is important in practical immune response network. Therefore, we propose a new immunity network model which, unlike the traditional immunity networks, has the same function that a $\mathrm{T}$ cell receptor has. We applied the proposed immunity network model and the traditional immunity network model to the pattern recognition system. And we compare performance of the proposed immunity network model with the traditional immunity network model, therefore showed usability of the proposed immunity network model.

キーワード : 免疫応答, 免疫的ネットワーク, $\mathrm{T}$ 細胞受容体, パターン認識システム

Keywords : immune response, immunity network, T cell receptor, pattern recognition system

\section{1. まえがき}

近年，生体の持つ優れた情報処理能力に学んで，コンピ ユータシステムに役立てようとする研究が盛んに行われて いる。特に脳や神経系に関するニューラルネットワークの 研究が数多く行われているが, 生体の免疫システムの持つ 情報処理能力も非常に優れており, 将来の並列分散型コン ピュータを考えるうえで重要である(1)。

その免疫システムを利用して, ロボットの自律行動 ${ }^{(2)}$, 最 適化(3)，ノイズ除去(4)などに応用しようとする試みがなされ ている。さらに, 免疫システムにおける免疫機構に着目し, そこで起こる各種の免疫反応による情報処理をパターン認

* 大分工業高等専門学校

下870-0152 大分県大分市大字牧 1666 番地

Oita National College of Technology.,

1666 Maki, oita 870-0152

** 富山大学

干930-8555 富山県富山市五福 3190 番地

Toyama University.,

3190 Gofuku, toyama 930-8555

*** 宮崎大学

T889-2192 宮崎県宮崎市学園木花台西 1 丁目 1 番地

Miyazaki University.,

1-1, Gakuen Kibana-dai, Nishi, Miyazaki 889-2192
識に応用しようとする研究も行われてきた ${ }^{(5)}$ 。免疫の働きを 端的に表すなら「自己」と「非自己」を見分け，「非自己」 を排除する働きと言うことが出来る(6)。この免疫の「自己」 と「非自己」の認識システムは精密かつ柔軟性に富んでお り，それを利用したパターンの認識システムを実現しよう とする研究が進められてきた。

しかし,これらの研究は $\mathrm{B}$ 細胞と $\mathrm{T}_{\mathrm{H}}$ 細胞の相互作用の基 本的な部分しか考慮していない。実際の免疫系の免疫応答 では， $\mathrm{T}$ 細胞（抗原）受容体「 TCR（ $\mathrm{T}$ Cell (antigen) Receptor)」が重要な働きをしていることが知られている。 この TCR での抗原認識の際, 従来は 1 つの TCR で 1 種類 の抗原しか認識できないと考えられてきた。しかし, 最近 の研究で, この TCR は抗原認識の際, 類似性を持った複数 の抗原に反応するという多様な認識をすることが証明され ている (7)。即ち，1つの TCR で類似性を持った複数の抗原 を認識することが出来る。

本論文では，これまでに構築された生体の免疫ネットワ 一クに基づく免疫的ネットワークに, それら TCR の認識多 様性を考慮した免疫的ネットワークを提案する。また, そ れらをパターン認識システムに適用し, TCR の認識多様性 
を変形したパターンの認識に対応させることで，従来では 不可能であった変形パターンの認識率の向上を図り, シミ ユレーションを行うことによって提唱するネットワークと 従来の免疫的ネットワークとを比較し, 認識率及び多様な 入力に対する認識における有用性を明らかにした。

\section{2. 免疫応答ネットワーク}

本章では, 抗原と $\mathrm{B}$ 細胞, $\mathrm{T}$ 細胞の相互作用による免疫 応答機構と TCR の働きを記述しモデル化する。

生体に侵入した抗原 $(\mathrm{Ag})$ はまず，抗原処理能力を持つ 細胞（B 細胞, マクロファージ, 樹枝状細胞などがあるが, 本論文では B 細胞に限定）に取り込まれる。

抗原 $\longrightarrow \mathrm{B}$ 細胞

B 細胞は取り込んだ抗原を部分的に消化し，その一部を 自分の細胞表面にある MHC 分子の裂け目に割り込ませ, 提示する。これを「抗原提示」という。

この抗原提示を $\mathrm{T}_{\mathrm{H}}$ 細胞（CD4T 細胞）が $\mathrm{T}$ 細胞受容体 （TCR）を通して認識する。TCR は抗原をそのまま認識す ることが出来ず, $\mathrm{B}$ 細胞が抗原を分解して作ったペプチド 抗原と B 細胞表面にある抗原提示細胞の表面にある $\mathrm{MHC}$ II 分子が結合したもののみを認識することが出来る(3)。これ は「自己」である MHC II 分子と「非自己」であるぺプチド 抗原を見分けるためである。

$\mathrm{MHCII}+$ ペプチド抗原 $(\mathrm{B}$ 細胞 $) \longrightarrow \operatorname{TCR}\left(\mathrm{T}_{\mathrm{H}}\right.$ 細胞 $)$

この抗原認識において, TCR は多種多様な抗原の特異性 を認識するため, 自らの遺伝子の再構築を行うことによっ てす心゙ての抗原に対応出来る多様性を生み出している。し かし近年の研究で, ペプチド抗原と TCR は常に 1 対 1 の反 応をするわけではないことが分かってきた ${ }^{(7)}$ 。TCR は抗原 特異性を有しているにもかかわらず，数多くのエピトープ （免疫反応を引き起こすことの出来る最小の分子単位）を認 識出来る。即ち, 類似性を有する複数のペプチド抗原を 1 つの TCR で認識することが出来る（図 1)。TCR は自ら多 様性を持っているだけでなく, その認識過程も多様性を持 っているといえる。

その多様性と柔軟性で抗原を認識した $\mathrm{TH}$ 細胞は自分自身 が活性化し， B 細胞へ抗体の産出及び増殖のシグナルとな るサイトカイン (白血球 (leukocyte) (リンパ球, マクロフ アージなど広義の白血球) 間の情報伝達を媒介する分子) を分泌する。

$\mathrm{T}_{\mathrm{H}}$ 細胞 $\longrightarrow$ サイトカイン（活性）

サイトカインのシグナルを受けた B 細胞はプラズマ細胞 （抗体産出細胞）に変化，抗体（Ab）を生産し抗原を排除す る。

$\mathrm{B}$ 細胞（プラズマ細胞）—抗体

分裂増殖した $\mathrm{B}$ 細胞の一部は, そのまま免疫系に温存さ れ免疫記憶細胞となり, 再度同じ抗原が侵入すると, 記憶 細胞は急速にプラズマ細胞（抗体産出細胞）に分化し短期 間に大量の抗体が産出される (2 次免疫応答 $)$ 。抗体により 抗原が排除されると, 過剰な抗体生産を抑えるサイトカイ

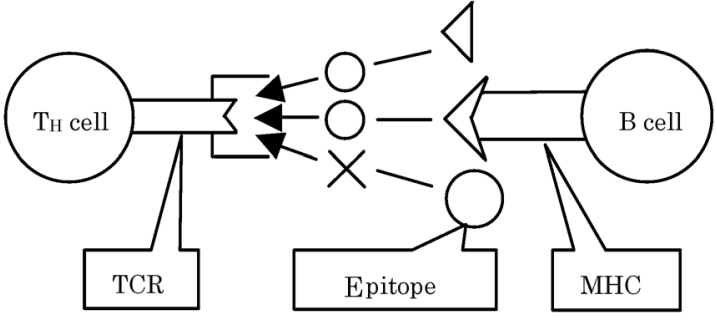

図 $1 \mathrm{~B}$ 細胞から $\mathrm{T}_{\mathrm{H}}$ 細胞への抗原提示

Fig. 1. Antigen presentation to $\mathrm{T}_{\mathrm{H}}$ cells from $\mathrm{B}$ cells.

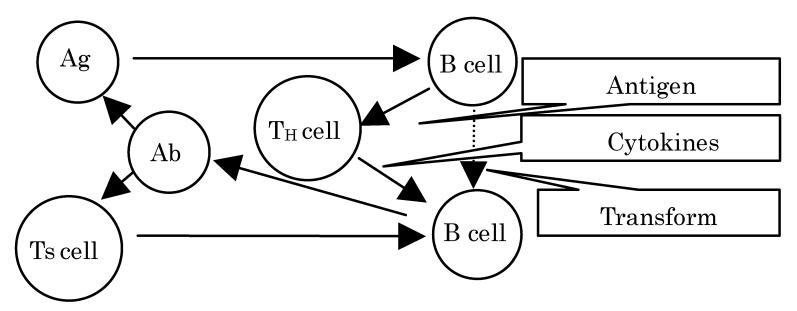

図 2 モデル化された免疫応答ネットワーク

Fig. 2. The model of the immune response network.

ンがサプレッサ $\mathrm{T}$ 細胞（ $\mathrm{T}_{\mathrm{S}}$ 細胞）より分泌され, 過剰な抗 体生産が抑制され免疫応答が終了する。

抗体 $\longrightarrow \mathrm{Ts}$ 細胞

$\mathrm{Ts}$ 細胞 $\longrightarrow$ サイトカイン（抑制）

以上が免疫応答のプロセスであり, これらの概略を図 2 に示す。

\section{TCR の認識多様性を考慮した免疫的ネットワ ーク}

〈3・1〉免疫的ネットワーク 2 章で記述した免疫応 答ネットワークを基に構築した免疫的ネットワークシステ ムを図 3 に示す。本論文では TCR の働きを, 変形した入力 の認識に対応付け，それを利用した免疫的ネットワークの 構築を試みる。ここで抗原 $(\mathrm{Ag})$ は入力ベクトルに対応し， $\mathrm{B}$ 細胞群は入力層, $\mathrm{T}_{\mathrm{H}}$ 細胞群は記憶層, $\mathrm{T}_{\mathrm{S}}$ 細胞は抑制層, 抗体 $(\mathrm{Ab})$ は入力ベクトルと選択, 想起された記憶ベクト ルとの誤差を表す。

まず，入力ベクトル $\overrightarrow{A g}$ が入力層である $\mathrm{N}$ 個の $\mathrm{B}$ 細胞群 に入力される。入力ベクトルの各成分がそれぞれ対応する $\mathrm{N}$ 個の B 細胞群に入力されるが, 入力された情報はそのまま 出力され, ある荷重ベクトルがかかって TCR を通してす心゙ ての $\mathrm{T}_{\mathrm{H}}$ 細胞（ $\mathrm{M}$ 個）に入力される。これはつまり, 抗原提 示である (図 4)。

ここで, $\mathrm{T}_{\mathrm{H}}$ 細胞に存在する記憶ベクトルを $\vec{T}_{j}$ とし，

$$
\vec{T}_{j}=\left(T_{1 j}, T_{2 j}, \ldots, T_{N j}\right),(j=1,2, \ldots, M)
$$

と定義する。

TCR の入力情報の認識は柔軟性に富んでいるため, 入力 
ベクトル $\overrightarrow{A g}$ と同種の変形ベクトル $\overrightarrow{A g_{x}}$ が入力された場合 も $\overrightarrow{A g}$ として認識されなければならない。そこで, $\mathrm{T}_{\mathrm{H}}$ 細胞 に存在する記憶ベクトルから作り出された $\vec{T}_{j} に$ 対する変形 ベクトルを $\overrightarrow{T_{j k}}$ とし,

$$
\overrightarrow{T_{j k}}=\left(T_{1 j k}, T_{2 j k}, \ldots, T_{N j k}\right),(j=1,2, \ldots, M)(k=1,2, \ldots, L)
$$

と定義する。 $L$ は変形ベクトルの種類数である。ここで,

$$
\overrightarrow{T_{j k}}=\overrightarrow{a_{j k}} \vec{T}_{j},(j=1,2, \cdots, M)(k=2,3, \cdots, L)
$$

とする。 $\overrightarrow{a_{j k}}$ は変形ベクトルを作るための行列であり,

$$
\begin{aligned}
\overrightarrow{a_{j k}} & =\left(a_{1 j k}, a_{2 j k}, \cdots, a_{P j k}\right), P=N \times N \\
& ,(j=1,2, \cdots, M)(k=1,2, \cdots, L) .
\end{aligned}
$$

とする。

この時の $\mathrm{T}_{\mathrm{H}}$ 細胞に入力されるベクトル $\overrightarrow{W_{j k}}$ は $\mathrm{T}_{\mathrm{H}}$ 細胞の 個数 $\times$ 変形ベクトルの個数分存在する。

$$
\overrightarrow{W_{j k}}=\left(W_{1 j k}, W_{2 j k}, \cdots, W_{N j k}\right),(j=1,2, \cdots, M)(k=1,2, \cdots, L)
$$

このベクトル $\overrightarrow{W_{j k}}$ は各 $\mathrm{T}_{\mathrm{H}}$ 細胞に存在する記憶と入力によ って定められ，次のように定義する。

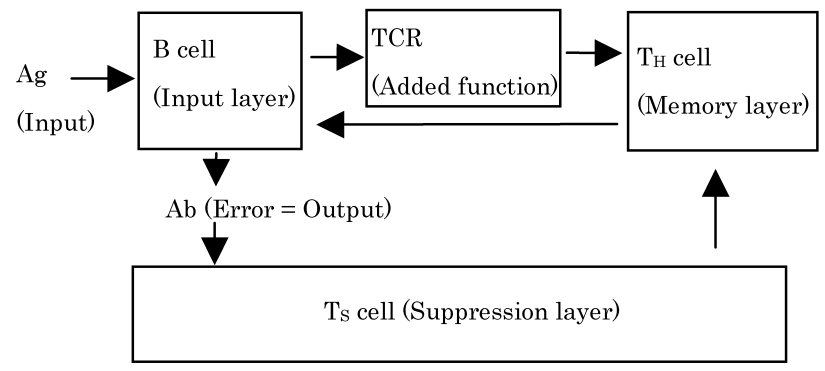

図 3 免疫的ネットワーク

Fig. 3. The immunity network model.

$$
\begin{aligned}
& W_{i j k}=\frac{A g_{i}}{T_{i j k}} \\
& \text { 但し, } \\
& T_{i j k} \neq 0 \text { かつ } T_{i j k}<A g_{i} \text { のとき } W_{i j k}=1 \\
& T_{i j k}=0 \text { のとき } W_{i j k}=0 \\
& \text { とする。 }
\end{aligned}
$$

また，図 4 における $\vec{W}_{j}$ は

$$
\overrightarrow{W_{j}}=\left(\overrightarrow{W_{j 1}}, \overrightarrow{W_{j 2}}, \cdots, \overrightarrow{W_{j L}}\right),(j=1,2, \cdots, M)
$$

である。

TCR を通して抗原提示を受けると $\mathrm{T}_{\mathrm{H}}$ 細胞内では荷重入 力和 $S_{j k}$ が求められる。

$$
S_{j k}=\frac{\sum_{i=1}^{N} W_{i j k}}{\left|\overrightarrow{T_{j k}}\right|}
$$

この $S_{j k}$ は， $\mathrm{T}_{\mathrm{H}}$ 細胞が持つ記憶ベクトルと入力ベクトル $\overrightarrow{A g}$ との適合度を表すもので, 適合度が大きいということは その二つのベクトルが同じ型として適合性があることを意 味する。すなおち, $\mathrm{T}_{\mathrm{H}}$ 細胞群内において最大の荷重入力和 $S_{j k \mathrm{MAX}}$ の值を示した $\overrightarrow{T_{j k}}$ が入力と適合したとして選ばれ, B 細胞へ出力される。

次にこの $\overrightarrow{T_{j k}}$ により刺激を受けた $\mathrm{B}$ 細胞のみが出力とし て抗体 $(\mathrm{Ab})$ を生産する。免疫的には, 過去に排除した抗 原の情報を記憶していた $\mathrm{T}_{\mathrm{H}}$ 細胞の指示を受け， $\mathrm{B}$ 細胞がプ ラズマ細胞へと変化し，抗体を生産することを指す。

この抗体（Ab）は入力ベクトルと想起された記憶ベクト ルとの誤差を表すものとする。

$$
A b=\sum_{i=1}^{N}\left|A g_{i}-T_{i j k}\right|
$$

そして, その出力された誤差はそのまま Ts 細胞への入力 となる。 $\mathrm{Ts}$ 細胞では抗体 $(\mathrm{Ab})$ とあらかじめ決められたパ ラメータ $\rho$ とが比較される。このパラメータ $\rho$ は入力ベク トルと記憶ベクトルの誤差をどの程度まで認めるかという

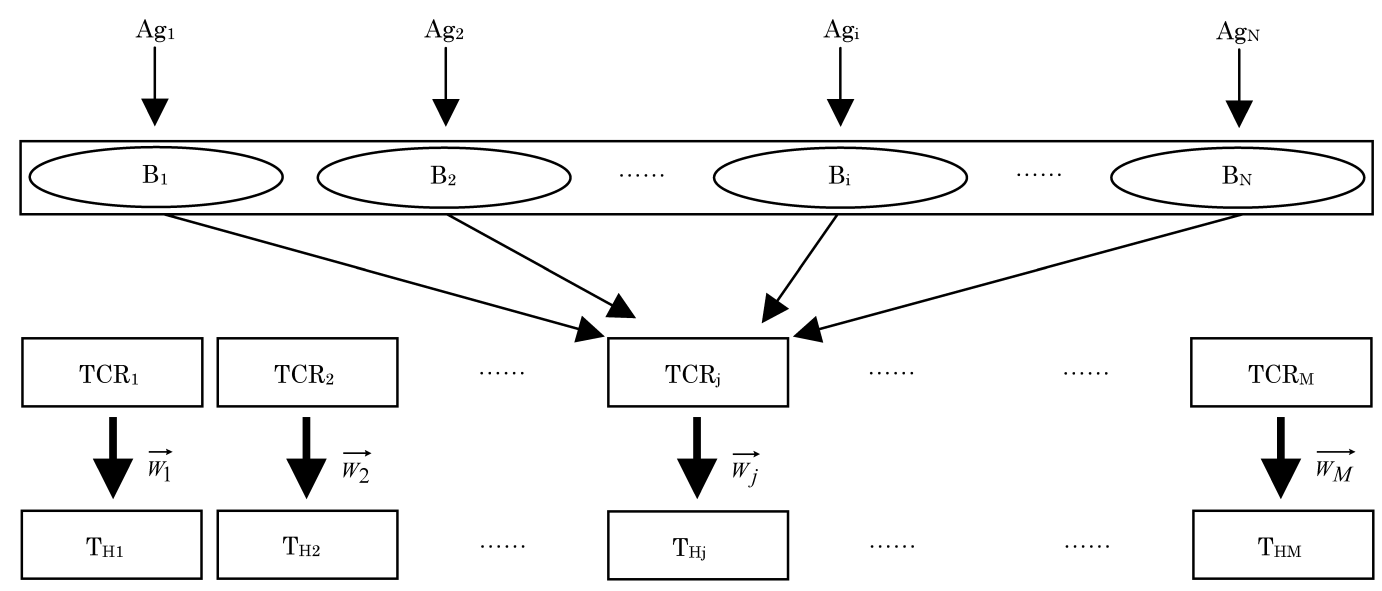

図 4 B 細胞から $\mathrm{T}_{\mathrm{H}}$ 細胞への荷重結合

Fig. 4. Weight connections form $\mathrm{B}$ cells to $\mathrm{T}_{\mathrm{H}}$ cells. 
ものであり，許容度と呼ぶ。誤差が許容度内であれば認識 が成立したことになり，各パラメータの更新すなわち学習 が行われる。

更新される前の記憶を $\vec{T}_{j}^{t=0}$, 更新された記憶を $\vec{T}_{j}^{t=1}$ とす ると, 記憶更新の式は

$$
\vec{T}_{j}^{t=1}=\left\{\frac{t \overrightarrow{a_{j k}} \overrightarrow{A g}+\vec{T}_{j}}{2}\right\}^{t=0}
$$

と定義される。ここで $\overrightarrow{a_{j k}}$ は $\overrightarrow{a_{j k}}$ の転置行列とする。この式 は選択された $\vec{T}_{j k}$ が $\vec{T}_{j}$ から変化している分を, $\overrightarrow{A g}$ にその逆 変化として与えることで, $\overrightarrow{A g}$ と $\vec{T}_{j}$ が対応出来るようにな り，記憶の更新が行われることを意味している。

このように入力ベクトルと記憶ベクトルの平均を取り， この後 “0”〜“1”までの離散值に丸め込む方法をとる。

誤差の総和が許容度を超えてしまった場合，想起された 記憶ベクトルに対応する荷重ベクトルの成分を一時的にす ベて 0 とする。これは免疫においては，Ts 細胞から抑制性 のサイトカインが分泌され, 興奮性のサイトカインを分泌 していた $\mathrm{T}_{\mathrm{H}}$ 細胞を抑制することにあたる。

このため, 再び $\mathrm{T}_{\mathrm{H}}$ 細胞群内で $S_{j k}$ を求める競合作業が始 められ，同様の手順で誤差の総和が許容度内になるまで繰 り返される。

但し，全ての $\mathrm{T}_{\mathrm{H}}$ 細胞が抑制されてしまってなお誤差の総 和が許容度以内の記憶ベクトルが存在しなかった場合は入 カベクトルが未知のベクトルであったとして，新たな認識 カテゴリーを $\mathrm{T}_{\mathrm{H}}$ 細胞群に形成する。つまり, 未知のベクト ルを新たな記憶ベクトルとする。

〈3·2〉 TCR が持つ認識多様性の工学的意味 本項で は，本論文で提案する TCR が持つ柔軟性に富んだ認識シス テムをパターン認識システムに利用した免疫的ネットワー クの工学的な意味について述べる。

1 つの TCR が類似した複数の抗原を認識できるという免 疫学的事象は，工学的に考えた場合，複数の相似性を持っ た変形パターンの認識と対応付けることが出来る。本論文 ではこの変形パターンの種類として, 回転したパターン, 位置ずれしたパターン，拡大・縮小したパターンを考慮す る。相似性を持ったパターンは，平面においてはこの三つ のパターン以外に鏡像も考えられるが，本研究ではパター ン認識システムとして画像認識システムを想定しており, 画像認識において鏡像は別のパターンであると考えられる ため, 鏡像は考慮していない。

ここで，パターンの変形は入力パターンと記憶パターン のつながりを変化させることによって実現する。

入力ベクトルを

$$
A g_{x y}\left\{\begin{array}{l}
x=0,1, \cdots, x_{\text {max }} \\
y=0,1, \cdots, y_{\text {max }}
\end{array}\right.
$$

とし，記憶ベクトルを

$$
T_{x y}\left\{\begin{array}{l}
x=0,1, \cdots, x_{\text {max }} \\
y=0,1, \cdots, y_{\text {max }}
\end{array}\right.
$$

とすると，通常の

$$
T_{x y}=A g_{x y}
$$

という各成分のつながりを組み換えた変形ベクトルを考慮 することで，仮想的に複数の入力パターンを認識している かのようにする。各成分のつながりパターンとして $90^{\circ}$ 回 転した場合,

$$
T_{x y}=A g_{y x \max -x}
$$

$180^{\circ}$ 回転した場合,

$$
T_{x y}=A g_{x \max -x y \max -y}
$$

$270^{\circ}$ 回転した場合,

$$
T_{x y}=A g_{y \max -y x}
$$

位置ずれした場合,

$$
T_{x y}=A g_{x+r y+s}
$$

拡大・縮小した場合，

$$
T_{x y}=A g_{m x} m y
$$

というそれぞれに対応した三つのつながりパターンが生じ る。この各成分のつながりの組み換えも TCR の抗原認識を 考慮したものである。TCR は抗原認識の際, 接触するアミ ノ酸残基の違いを識別するが, 最近の研究で, ある TCR の 認識は抗原の TCR 接触アミノ酸残基の隣接アミノ酸残基あ るいは非接触アミノ酸残基の影響を受けるという報告があ る(8)(9)。これらの現象は抗原ペプチド中の特定のあるアミノ 酸残基の置換によってペプチドの立体構造に変化をきた し, 置換した部分から離れた TCR 接触残基と TCR の相互 作用に影響を与えることと示唆している ${ }^{(7)}$ 。これ工学的に 応用したのが上述した各成分の組み換えとなる。このよう なパターンの成分の組み換えをすることによって変形した 入力パターンに対応する。これが TCR の認識多様性の工学 的意味である。

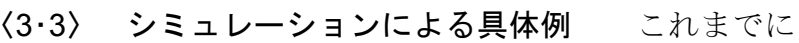
述べた免疫的ネットワークの認識・学習過程を, 具体例を 用いて説明する。このシミュレーション例では, 許容度 $30 \%$ において, 1 つのパターンだけが記憶されている場合に, そ の記憶パターンの変形パターンが入力として与えられた場 合の認識過程を示す (図 5)。

まず, Step1 では, 入力パターンと記憶パターンとの適合 度, 及び, 入力パターンと記憶パターンの変形パターンと の適合度が計算される。この時, 入力パターンと記憶パタ ーンのつながりを(14-1)(14-2)(14-3)(15)(16)式に従い, 組み 換えることで図 5 のような記憶パターンの変形パターンと の適合度を計算することが出来る。実際には様々な変形パ ターンを考えることが出来るが, シミュレーション例では 3 つの変形パターンだけを考慮することにする。次に, Step2 では, 最大荷重を示したパターンが選ばれ, 入力パターン 


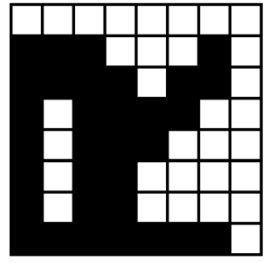

Input Pattern

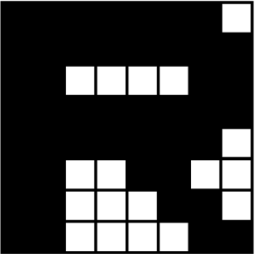

Memory Pattern

Matching rate $=0.457$

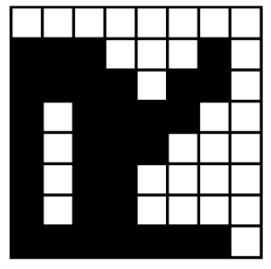

Input Pattern
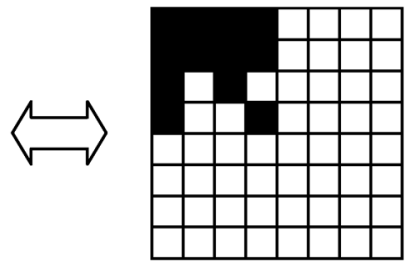

Transformation Pattern 1

Matching rate $=0.583$

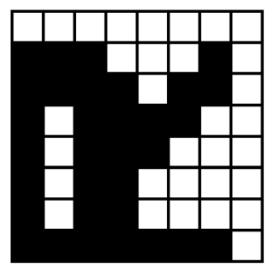

Input Pattern

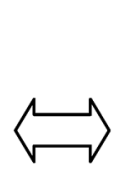

Transformation Pattern2

Matching rate $=0.629$

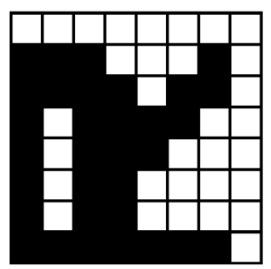

Input Pattern
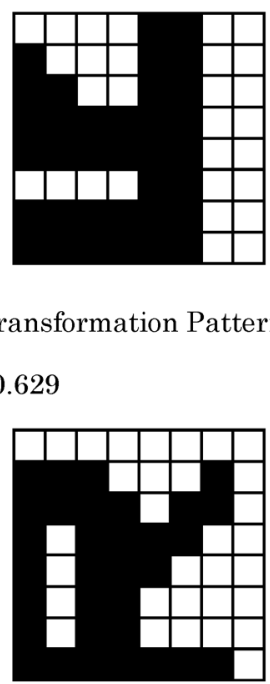

Transformation Pattern3

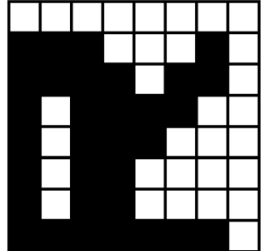

Input Pattern

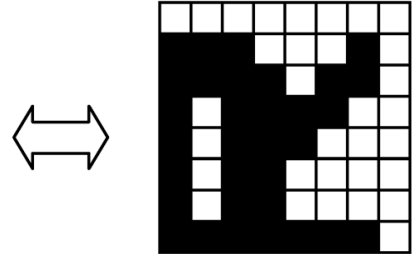

Transformation Patterı
Error $=0>19.2$ (Tolerable Error) $\rightarrow 0$

Step2 : Error check

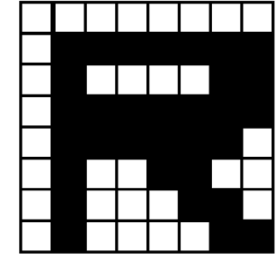

Input Pattern

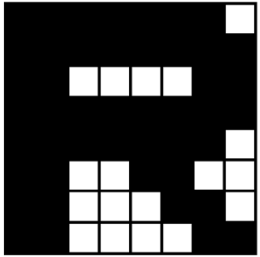

Memory Pattern
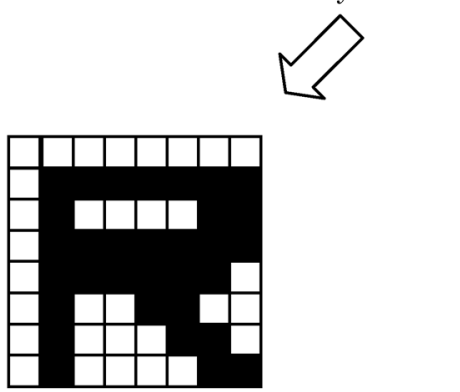

Renewal Memory Pattern

Step3 : Renewal

Matching rate $=1$

Step1 : Matching

図 5 シミュレーション例

Fig. 5. Simulation example.

と選択されたパターンとの誤差が計算される。この場合， 誤差は 0 であり,許容誤差 $30 \%$ すおわち 19.2 と比較すると， 許容範囲内であるので, 入力パターンは記憶パターンの変 形パターンであると認識される。従って, Step3 で記憶の更 新が行われる。この時, 入力パターンをそのまま記憶パタ ーンに学習させるのではなく,(10)式に従い入力パターンと 記憶パターンが対応出来るようにし，記憶の更新を行う。

\section{4. シミュレーション}

〈4·1〉 シミュレーション TCR の認識多様性を考慮 した免疫的ネットワークを検証するため, パターン認識に
このネットワークを適応した。また，TCR の認識多様性を 考慮したネットワークの性能を検証するため, TCR の認識 多様性を考慮していないネットワークとの比較を行った。 シミュレーションを行うにあたって利用した条件は，16 $\times 16$ 要素 $\times 4$ 值によって構成された 10 パターンを用意して おき, 入力はその 10 パターンの中からランダムに 1 つのパ ターンを選び，そのパターンにノイズを付加し，さらにラ ンダムに回転，位置ずれ，拡大・縮小の変形を行ったパタ ーンを使用し， $\mathrm{T}_{\mathrm{H}}$ 細胞層の初期記憶有り（あらかじめ 10 パターン全てを記憶として保持させておく), 繰り返し回数 を 100 回の条件で行った。 


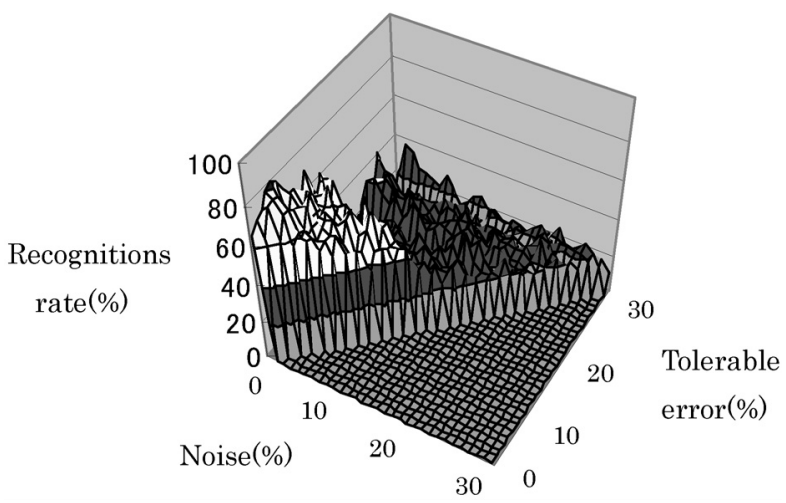

図 6 TCR の多様性を考慮した免疫的ネットワークの認識 率についてのシミュレーション結果

Fig. 6. Simulation result of recognition rate by immunity network with TCR function.

これらの条件の元で, TCR 機能を考慮したネットワーク の出力と, TCR 機能を考慮していない従来のネットワーク それぞれの出力を, 入力パターンに付加するノイズの量と 許容度を変化させ，そのときの認識率を図 6 及び図 7 に示 す。図中の $\mathrm{x}$ 軸は付加したノイズの量（\%）を，y 軸は許 容度 $\rho （ \%)$ を， $\mathrm{z}$ 軸は認識率（\%）を示す。認識率は, 初期記憶された記憶パターンと同一のパターンの変形ベク トルを入力として提示したとき, 初期記憶位置に分類され た率を示している。

〈4·2〉 考 察 シミュレーション結果について考 察する。図 6 と図 7 を比較すると, TCR を考慮していない ネットワークに比べTCRを考慮したネットワークでは大幅 な認識成功率の向上が見られた。しかし, TCR を考慮した ネットワークにおいて, 許容誤差を増加させるに従って認 識率が低下しているのが分かる。これは, 許容誤差が大き くなることで誤差の少ない別の記憶パターンが選択されて しまうことによる。また，これにより記憶パターンの更新 が行われ, 記憶パターンが劣化することも原因の 1 つであ る。

また, 今回シミュレーションにおいて, 位置ずれ, 拡大・ 縮小については Nearest Neighbor 法に相当する結線を行 った。これによりパターンが劣化されてしまい認識率の低 下を招いたと考えられる。この問題点は, Bilinear 法や Bicubic 法を用いることで解決可能であると考えられるが,

Bilinear 法や Bicubic 法を用いるとシミュレーションにお ける時閒が膨大になり，また，ハードウェア化する際に Bilinear 法や Bicubic 法に相当する結線を行う場合, 演算回 路が必要であり, 実用性を考慮した結果, 今回は Nearest Neighbor 法を用いた。

\section{5. むすび}

本論文では，これまでに提唱されてきた免疫的ネットワ ークに加え TCR（T 細胞受容体）の認識多様性を考慮した 免疫的ネットワークを提唱した。また，そのシミュレーシ

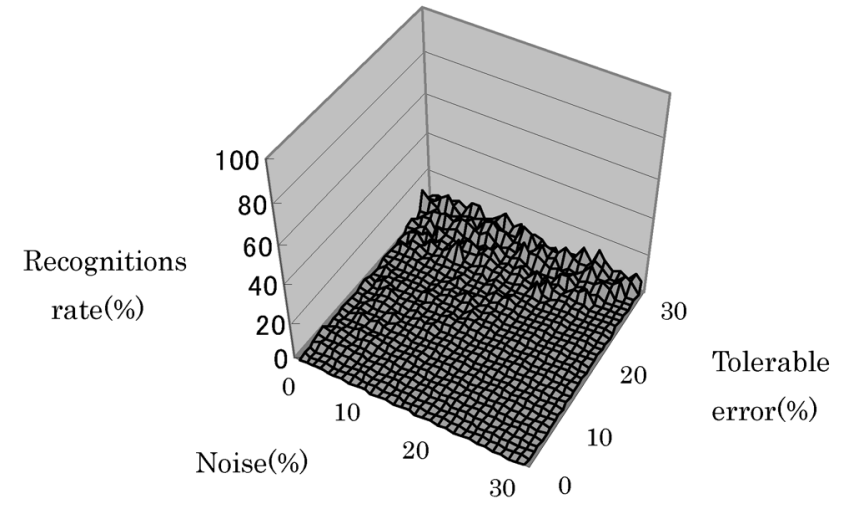

図 7 TCR の認識多様性を考慮しない免疫的ネットワーク の認識率についてのシミュレーション結果

Fig. 7. Simulation result of recognition rate by immunity network without TCR function.

ヨンを行い, 従来の免疫的ネットワークに比べ TCR の認識 多様性を考慮した免疫的ネットワークでは, パターンの変 形に対する認識率を向上させることに成功し, その有用性 を示した。

今回はTCR の認識多様性を工学的に応用しその部分的な 機能の向上を図ったが, 免疫系にはまだ多くの機能が存在 する。今後それらのさらなる仕組みについて研究を進め, それらを工学的に応用する試みが，引き続き行われること が期待される。

(平成 18 年 5 月 23 日受付, 平成 19 年 6 月 7 日再受付)

\section{文献}

(1) C. C. Langton, Ed : "Artificial life", MIT Press (1995)

(2) Y. Ishida : "An Immune Network Approach to Sensor-Based Diagnosis by Self-Organization", Complex Systems, Vol.10, pp.73-90 (1996)

(3) Y. Ishida and N. Adachi : "Active noise control by an immune algorithm: Adoption in immune system as an convolution", Proc.ICEC 96, pp.150-153 (1996)

（4）森 一之・築山 誠・福田豊生：「多様性を持つ免疫アルゴリズムの 提案と負荷割り当て問題一の応用」, 電学論 C, 133, 10, pp.872-878 (1993)

（5）田島浩一・唐 政・石塚興彦・淡野公一：「B 細胞の相互作用を考慮 した免疫的なネットワークによるパターン認識」, 信学論 D- II, J84-D-II , 2, pp.795-804 (2002)

（6）多田富雄：「免疫・「自己」と「非自己」の科学」, NHK ブックス, (2001)

（7）植村靖史・西村泰治：「 CLIP 置換型インバリアント鎖遺伝子ライ ブラリーを用 いた自己反応性 CD4+T 細胞が認識する抗原ペプチド の多様性の解析」, 臨床免疫, 37, 2, pp. 156-164 (2002)

(8) L. J. Ausubel, C. K. Kwan, and A. Sette, et al : "Complementary mutations in an autigenic peptide allow for crossreactivity of autoreactive T-cell clones", Proceedings of the National Academy of Sciences of the United States of America, 93:15317 (1996)

(9) G. R. Leggatt, A. Hosmalin, and C. D. Pendlcton, et al : "The importance of pairwise in teractions between peptide residues in the delincation of TCR specificity", Journal of Immunology, 161:4728 (1998) 


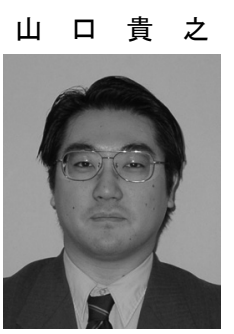

（正員） 2000 年宮崎大学大学院博士後期課程 システム工学専攻単位取得退学。2000 年大分 工業高等専門学校電気電子工学科助手を経て, 現在電気電子工学科講師。主としてニューラル ネットワーク等の研究に従事。工博。

深田斉仙

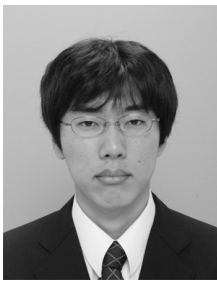

荒 巻 泰 崇

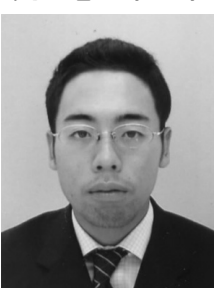

唐

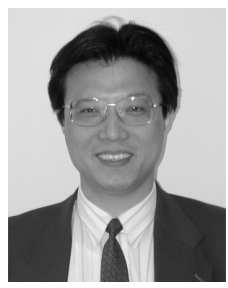

政 年清華大博士課程修了。1988 年清華大 · . 微電子学研究所講師。1989 年宮崎大研究生。 1990 年宮崎大 $\cdot$ 工・電子工学科助手。1993 年 宮崎大 ・ 工 ・ 電気電子工学科助教授。2000 年 富山大 - 工 ・ 知能情報工学科教授。生体情報処 理, ニューラルネットワーク, モバイルコンピ ユーティング等の研究に従事。工博。

田 村 宏 樹

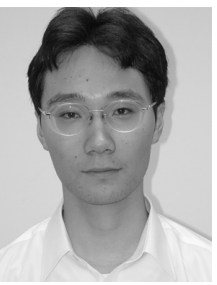

石 井 雅 博

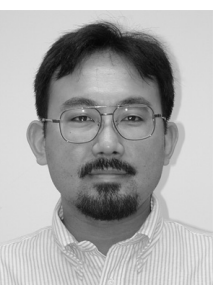

（正員） 1998 年宮崎大・工・電気電子卒業。 同年同大学院修士課程入学。2000 年同大学院 修士課程了。同年旭化成工業（株）入社。2001 年富山大 · 工 - 知能情報工学科教務職員。2006 年宮崎大 $\cdot$ 工・電気電子工学科助手。現在に至 る。ニューラルネットワークの研究に従事。

（非会員） 1995 年東工大博士課程修了。同年 York Univ ポスドク。1997 年東工大精密工学 研究所助手。2000 年富山大学工学部講師を経 て, 現在大学院理工学研究部准教授。知覚情報 処理, ヒューマンインタフェース, ソフトコン ピューティングの研究に従事。電子情報通信学 会, 情報処理学会, VR 学会, 視覚学会, Vision Sciences Society 各会員。工博。 